\title{
Cartographies of the 'Eastern Question': Some Considerations on Mapping the Sea of Marmara and the Black Sea in the Nineteenth Century
}

\begin{abstract}
The Sea of Marmara, the Black Sea, and the Bosporus and Dardanelles straits have always been geographically and, therefore, politically crucial for the state ruling Istanbul. Centuries of intermittent warring between the Ottoman Empire and their enemies often pivoted on the quality of naval knowledge of this region. In this article, I aim to give an overview of how cartographical developments progressed alongside the geo-political struggles in this area, and sometimes played a role in them. I suggest that map-making was particularly important during the 'long' nineteenth century of the 'Eastern Question', which can be dramatized as a play entitled 'The Balance of Power', in which the Ottomans, France, Russia and Britain were the main actors to take the stage. This period was full of struggle and conflict, treaties and alliances, and ended in 1895 with establishment of the first modern cartography unit within the Ottoman military.
\end{abstract}

\section{Introduction}

Historically, the Sea of Marmara and the Black Sea constituted an integral geographical unit, along with the Bosporus and the Dardanelles. Most importantly, the state ruling Istanbul always needed to control this unit for its food supplies, security and commerce. Indeed, the Byzantine Empire and the Ottoman Empire were aware of this phenomenon and acted accordingly to seek control of the entire unit (İnalcık 1979, p. 74).

\footnotetext{
An earlier version of this paper was presented at the "Global Traffic: Production and Circulation of Knowledge and Ideas across the Borders" International Workshop, within the framework of the Marie Curie projects CIG TECHDEM: Technocracy and Democracy: convergence, conflicts and negotiations. A comparative and global analysis of expert knowledge and political power (18th to 21st century), and IRSES WORLDBRIDGES: Philosophy of History and Globalization of Knowledge. Cultural Bridges Between Europe and Latin America (23-24 June 2016, Madrid).
}

Kaan Üçsu, University of Istanbul (UI)

๑ OpenAccess. ( 2018 Kaan Üçsu, published by De Gruyter. (cc) BY-NC-ND This work is licensed under the Creative Commons Attribution-NonCommercial-NoDerivatives 4.0 License. https://doi.org/10.1515/9783110492415-019 
Ottomans had begun to settle around the Bosporus and the Dardanelles soon after their emergence onto the stage of history. They began to populate the eastern shores of the Bosporus during the Battle of Pelekanon in 1329, and around Dardanelles through the conquests of Gallipoli in 1354 and Adrianapoli in 1361 (Inalc1k 2008a, p. 65). They then initiated a fortification process in order to maintain their existence in these areas. Although these activities and the fate of the region preoccupied Byzantine-European alliances, the dominance of the straits by the Ottomans after a series of conflicts, brought this era, inevitably, to an end with the conquest of Istanbul in 1453 by Mehmed II (1451-1481).

The conquest of Istanbul by the Ottomans dramatically changed politics in the west. Upon realizing that Europe would not like to leave Istanbul and its environs to the Ottomans, Mehmed II hurried to consolidate his power to impede probable attacks from enemies. To this end, his navy set sail in the Black Sea and the Aegean Sea in 1454 and 1455 respectively. Its venturesome campaign in the Aegean Sea resulted in the capture of some crucial northern Aegean islands. In response, the Venetian endeavor to establish a crusade against Ottoman expansion actualized on 1 March 1456. In the early years of this crusade, Western allies captured some islands in the Aegean Sea. However, the Ottoman navy strengthened its presence in the region by the conquest of Midilli in 1462 and by the construction of fortresses on both sides of the Gallipoli Strait in 1463-1464 (İnalcık 2008b, pp. 45-49). Ottoman expansion continued in the Black Sea. They imposed a duty on Genoese colonies in 1454 and on the Pontus Empire in 1456. By the conquest of Amasra and Trabzon in 1459 and 1461 respectively, they dominated the southern part of the Black Sea. Thus, the Ottoman State secured the protection of Istanbul and emerged as an imperial power within ten years (İnalc1k 2008b, pp. 51-52)

In the face of this Ottoman success, the Venetians constituted an alliance in 1463 with Uzun Hasan, sultan of the Aq Qoyunlu dynasty-enemies of the Ottomans in the east. That started a new war that lasted almost 16 years, and ended with the resounding defeat of the Venetians in 1479 (Inalc1k 2008b, pp. 50 -51). Meanwhile, Mehmed II continued to struggle for control in the Black Sea. Having closely monitored the problems between the Crimean Khanate and the Golden Horde Empire, and the emergence of Russia as a power, he eventually sent the navy to conquer Caffa and annexed the Crimean Khanate in 1475 (Inalc1k 1944, p. 206). Even though the conquest of Caffa rendered the Ottomans the most powerful actor in the Black Sea, they continued to expand by capturing Copa and Anapa in Circassia in 1479, and Akkerman and Kilia in Moldavia in 1484. Finally, the conquest of Southern Bessarabia (Budjak) in 1538 rendered the Black Sea an Ottoman lake (İnalcık 1979, p. 108). 


\section{The emergence of Russia}

This Ottoman dominance over the Black Sea region threatened Poland and the emerging power Russia. Therefore, these two states tacitly (and sometimes overtly) supported Kazakh tribes consisting of Tatarians and Circassians against the Ottomans and the Crimean Khanate from the seventeenth century onwards (İnalc1k 2008c, pp. 60-61). Assaults by these tribes forced the Ottomans to war with Poland and Russia in the second half of the seventeenth century. These attacks and wars burdened the Ottoman Empire, causing the failure of its Vienna Campaign in 1683.

Taking advantage of the situation, Russia attended the Holy League in order to realize its ambitions over the Black Sea. Sixteen years of war ended in the defeat of the Ottoman Empire and the Treaty of Karlowitz was signed in 1699. However, Russia did not accede to an agreement with the Ottoman Empire. The two empires decided to continue peace talks in Istanbul, where they signed a treaty in July of $\mathbf{1 7 0 0}$ leaving the castle of Azov, its dependent castles and the body of water between them to Russia. In return, the Ottomans imposed their conditions regarding territorial issues and rejected Russia's demand for free trade in the Black Sea (Özcan 2001, pp. 504-507).

That Russia's first attempt to rule the Black Sea was blocked by diplomacy did not eradicate its ambitions. From then on, Russia built a comprehensive plan for the Black Sea and, accordingly, the Mediterranean Sea. A new war started between Russia and the Ottoman Empire in 1735. During the four-year course of the war, the Russian foreign minister Heinrich Andrei Ostermann (1686-1747) elaborated a program to install Russia's presence in the Black Sea, and its expansion towards Moldavia and Wallachia. Although Russia's failure in this war denied them the chance to realize it during his lifetime, Ostermann's program later bore fruit in the 1768-74 war (Ledonne 2006, pp. 3-4, 8). This six-year, intermittent war ended with Russia's triumph and constituted a landmark regarding the destiny of the so-called 'Eastern Question'.

According to the Treaty of Küçük Kaynarca, signed in 1774 at the war's end, Russian commercial ships would be able to sail the Black Sea and the Straits (Beydilli 1992, p. 266). These developments prompted indignation throughout the West and a 'play' called the 'Balance of Power' begun to be enacted upon the stage of the aforementioned historically and geographically significant unit comprising the Sea of Marmara and the Black Sea. Russia's destruction of the Ottoman fleet in Çeşme in 1770 had turned the tables on the Ottoman Empire (Aktepe 1993, p. 288-289). This overwhelming defeat prompted the Ottoman court to carry out radical reforms in education, as well as in the navy. 


\section{Explicit France, implicit Russia}

In this context, I suggest this turning point as the beginning of a 'long' nineteenth century for the Ottoman Empire, which ended in 1895 with its establishment of a modern unit for cartography within the ministry of war. In fact, the Ottoman Empire had already initiated a modernization project within its army in the second quarter of the eighteenth century, but was unable to maintain it due to diverse political and economic reasons, and the lack of a qualified labor force (Kaçar 2008, p. 71). The Ottomans undoubtedly needed help in order to realize the modernization of their army and education system. An opportunity thus arose, and the first actor to take the stage was France. They lent a hand to their old friend in organizing and servicing the institutions needed to prevent Russia from emerging as a power. They deployed French engineers and cartographers to the newly established military schools in Istanbul, and provided those schools with educational materials and instruments (Günergun / Üçsu 2016, p. 148).

One of the first outcomes of this new collaboration was a map of Princes' Islands, which was made by copying a Turkish map acquired in 1772 (BnF, GE SH 18 PF 98 BIS DIV 6 P 6D). In the same year, a French engineer named Bellin produced a map of the Black Sea in which its southern part is excessively distorted (BnF, GE SH 18 PF 99 DIV 0 P 18). It appears that he had not used Turkish maps, since one that represented the southern region and the Sea of Azov far more precisely had already been published by Ibrahim Muteferrika almost 50 years earlier, in 1724. In fact, Müteferrika's map had already been copied and translated into French in 1768 by a French dragoman named Chabert, in the service of a Neapolitan diplomatic envoy (Ucsu 2017). Apparently, a patron of Müteferrika named Mehmed Said Pasha did not give this map as a present to the royal library of France during his mission to Paris in 1742, presenting instead the 'officially' published books, including Katip Çelebi’s Cihannüma (Aubaile et al. 1999, pp. 326-327).

Likewise, Müteferrika's had not reached the Russians either. Thus, Bellin's chart was probably the one in greatest use among the Russian navy too (Schokalsky 1907, p. 632). When war erupted in 1768, Catherine the Great (17291796) ordered her ambassador to obtain maps. Thereupon, the Russian ambassador in London, Count Ivan G. Chernyshov (1726-1797), had a famous Londonbased map seller called Andrew Dury prepare a map of the Black Sea in 1769, using the maps Chernyshov provided him (Zaytsev 2000, p. 114; Bulatov / Delano-Smith / Herbert 2001, pp. 72-76). Although we do not know which maps the 
ambassador gave Dury to work with, we can conclude from the resulting map's inadequacy that they did not include Müteferrika's.

Towards the end of the war, in 1773, Russia sent a small squadron to survey the northern Black Sea, of which a map did not reach their Admiralty until 1782. While serving in the Russian navy during the war, Dutch officer Jan-Hendrik van Kinsbergen produced a map of the Crimean peninsula and the Sea of Azov, which was then the most reasonable map of the related area despite its lack of detail concerning the bay and inlets west of Balaklava, where the harbor of Sevastopol would later be located (Zaytsev 2000, pp. 114-116).

Meanwhile, Russia began in 1769 an expedition in the Aegean Sea, which was their "first large-scale strategic naval campaign conducted at a distance from Russian shores” (Bulatov 2000, p. 101), lasting until 1774. This expedition was of great importance in terms of the ongoing war and the destruction of the Ottoman fleet in Çeşme; it also "laid the foundation of the future Black Sea fleet". Russia most probably could not chart the Straits and the Sea of Marmara during this expedition, since they lacked sufficient time to do so (ibd.). Nevertheless, immediately following the signing of the Treaty of Küçük Kaynarca, Russia made a considerable number of charts of the Sea of Marmara and the Straits, which contravened the terms of the treaty. Its disguised surveying activities until late 1778, when their output was published as the Atlas of the Archipelago (Bulatov 2000, p. 108). Over the course of these voyages, as well as using French and English charts, Russian surveyors acquired and used Ottoman charts unhesitatingly, despite their Admiralty's contempt for Ottoman scientists (Postnikov 2000, p. 86).

Out of gratitude to the French government for their aid during the war and for the foundation of new schools, the Ottomans provided French scientists with the privilege of surveying the Straits and the Sea of Marmara. Choisseul Gouffier (1752-1817) in particular was employed as ambassador to Istanbul in 1784, and the officers he patronized made many measurements and maps of those waters. The scientists in his team-most notably Achille Tondu, Jean François Truguet (1752-1839), Jean Baptiste Lechevalier (1752-1836) and François Kauffer (c1751-1801)-taught at the new Ottoman engineering schools and published works in Turkish as well (Vagnon / Hofmann 2016, pp. 39-47; Zorlu 2011, pp. 79-80).

François Kauffer merits special mention here for the sake of this paper. He had come to Istanbul in 1776 for no more than a month in the entourage of Gouffier's famous Voyage Pittoresque de la Grèce. From his map of Istanbul published in 1786, it can be understood that he had also prepared a map in 1776. However, considering the limited duration of his visit, the earlier one must have been a cursory map. His second venture to Istanbul occurred in 1784, when Gouffier 
was appointed ambassador. This time, Kauffer conducted a six-month triangulation survey of Istanbul in collaboration with Lechevalier, beginning in December 1785. As a consequence, a revised version of abovementioned 1776 map was published (Pedley 2012, pp. 32-36) In 1788 he published a map for the Ottomans of the northern part of their territory, annotated in both French and Turkish.

When his patron returned to France due to the French Revolution in 1789, Kauffer was stuck in a difficult situation. In 1792, after losing the Grand Vizier's letter to his patron, he was arrested and imprisoned for some time. Upon his release, he returned to Istanbul to serve the Ottoman court. However, according to recently discovered information, it appears that Kauffer served not only the Ottomans: he also sold spatial knowledge about Ottoman domains to the Russian ambassador in Istanbul for six times more than his Ottoman court earnings. Kauffer's service to Russia was not limited to his own maps and surveys-he also used his position to offer Turkish government maps and surveying reports to the Russian Empire (Frumin 2016, pp. 95-102). Meanwhile, Kauffer's former patron Gouffier was exiled to Russia, where he was warmly welcomed by Russian officers in St. Petersburg. Their excessive hospitality has raised suspicions that Gouffier may also have provided Russians with spatial knowledge. Taking into consideration that Russia and the Ottoman Empire formed an alliance in reaction to the invasion of Egypt by France in 1798, it is hard to say whether these activities constituted espionage or diplomatic maneuvers (Pedley 2012, p. 37, note 23).

\section{The invasion of Egypt and new mapping activities}

The French invasion of Egypt also gave an opportunity to the British, who sent a military mission to Istanbul in 1799 to assist the Ottomans. During this mission, the British navy examined the defensive capacity of the Dardanelles (Chasseaud / Boyle 2005, p. 50). According to the report filed by Major M. Hope, the situation was quite poor to defend the Dardanelles and, accordingly, Istanbul (Hope 1918, pp. 118-119).

The Ottoman-Russian coalition against France did not last long, and a new war between them erupted in 1806. Russia and France came together to negotiate plans to share the Ottoman domains. The Ottoman Empire in turn approached Britain, and signed the Treaty of the Dardanelles in 1809. With this treaty, Britain accepted that the Ottoman Empire had the right not to permit warships to pass through these straits (Beydilli 1992, p. 266). This treaty granted Britain its 
invitation to appear onstage-and their entry heralded France's exit. French expeditions in Ottoman territories dramatically diminished. One of their few important mapping activities that warrants mention here is Antoine François Andreossy's (1761-1828) book, which was translated into English in 1818 (Lebouteiller 2016, pp. 85-87).

Meanwhile, Russia's keen interest in the area continued apace. The Ottoman Empire had abolished its Janissaries in 1826 and had been trying to reorder its army. Sultan Mahmud II (1808-1839) was thus inclined to make an agreement with Russia, so as to gain time and to prevent a probable Russian assault. The Akkerman Convention treaty was signed in this context, re-asserting the right of Russian ships to pass through the Straits and sail on the Black Sea for commercial reasons (Beydilli 1992, p. 266). Russia launched an expedition under the command of Captain Egor Pavlovich (1796-1859) in the Black Sea in 1826, which lasted ten years. This expedition's output, titled Atlas of the Black Sea, was published in 1842, and was subsequently used for more than 30 years thereafter (Grinevetsky et al. 2015, p. 59, 511-512; Komaritsyn / Miroshnikov 2002, p. 105).

In the meantime, Britain was eager to survey the Sea of Marmara and the Black Sea after establishing their presence on the region's stage by their alliance with the Ottomans. British intellectual Edmund Goodenough, writing of the British expedition conducted in 1829 on the Black Sea, noted that "Of all the waters of the deep which have been penetrated by the enterprise of British sailors, there are none so little known to us, by actual observation, as the Black Sea" (Goodenough 1831, p. 101). The situation was slightly better regarding the Sea of Marmara. In 1833, a British expedition had started in the north of the Aegean Sea under the tutelage of Thomas Graves (1802-1856). Among its team was Thomas Abel Brimage Spratt (1811-1888), who was later charged with a crucial survey of the Dardanelles and of Troy in 1840, which resulted in a map published in 1844 (Chasseaud / Boyle 2005, p. 50).

Another map of the Sea of Marmara, with the inlets of the Dardanelles and the Bosporus marked, was printed on 29 August 1840 by the publishing house of the Ottoman Navy (Günergun / Üçsu 2016, p. 154). Considering that, according to the extant records, the Ottoman navy did not conduct an independent expedition on the Sea of Marmara at that time, and that the Sea of Marmara had then yet to be adequately surveyed, we could infer either that some Ottoman officers had participated in aforementioned British expedition, or that they had acquired its results immediately thereafter and compiled this map. The Ottomans' first independent expedition on the Sea of Marmara took place under the command of Ahmet Hoca in 1841 and was completed in three years, resulting in a map in 1844 (Algül 1985, p. 64). Immediately following this expedition, Russia made an offer to the Ottoman Empire to survey the Sea of Marmara together. This survey, of 


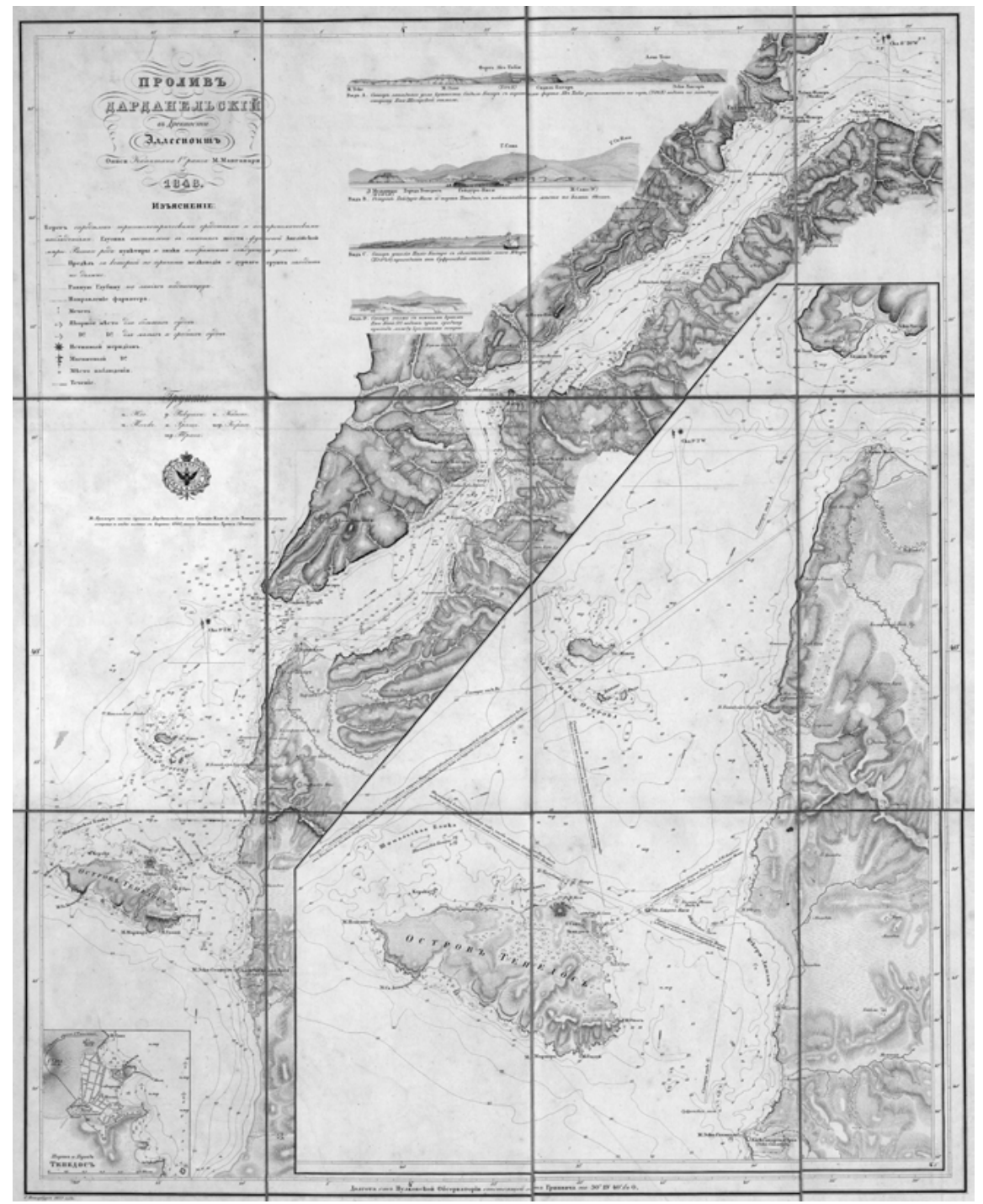

Fig. 1a State Archives of Prime Ministry BOA HRT 706

which the commander was E. P. Manganari, began in 1845 and lasted three years. The results of this expedition were published in the Marmara Guide and used by seamen and navies for a considerable time thereafter (Aygün 1936, pp. 63-64). (Fig. 1a and 1b) 


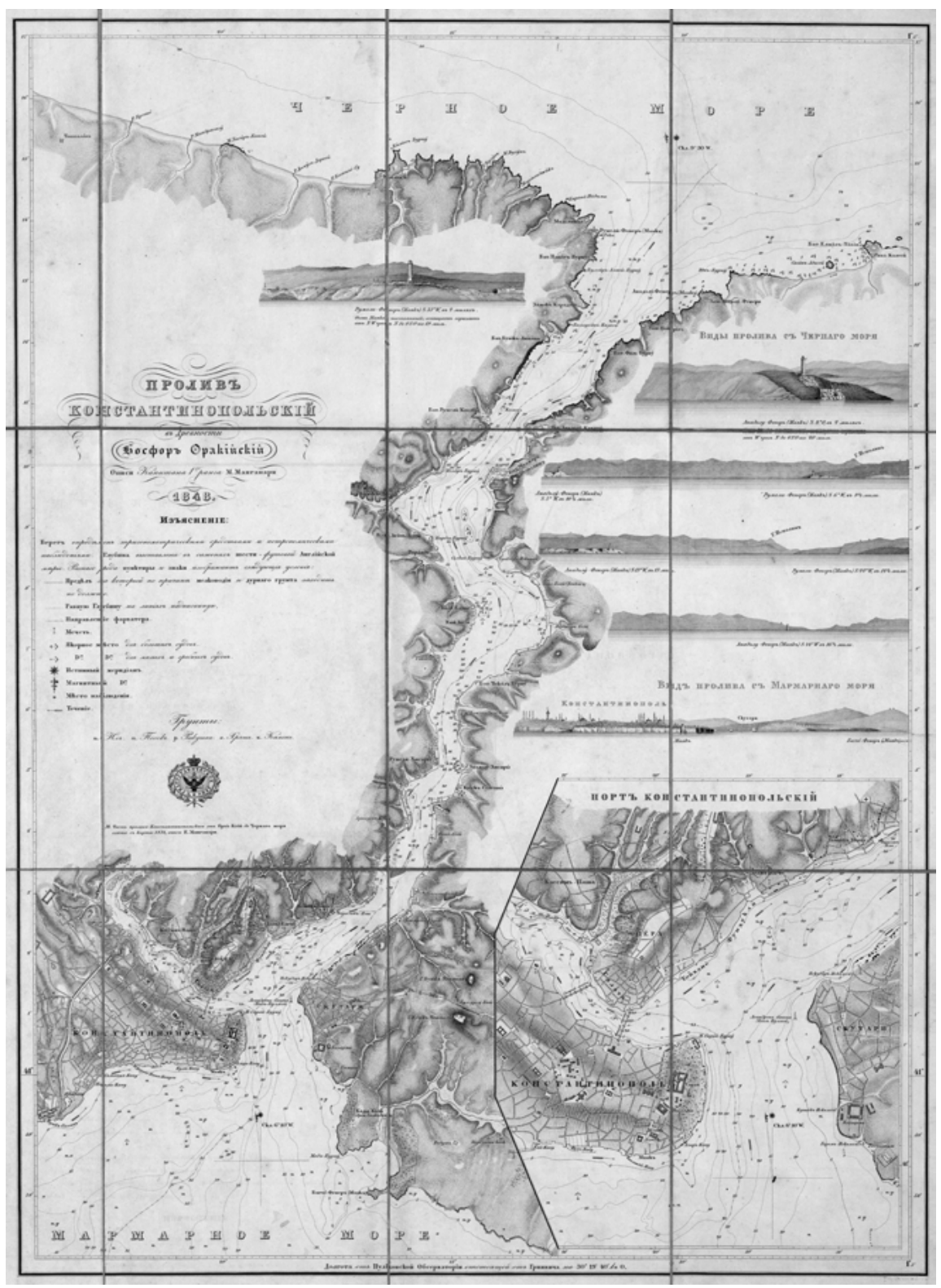

Fig. 1b State Archives of Prime Ministry BOA HRT 706 


\section{Mapping during the Crimean War}

This quiet period came to an end in 1853. Russia declared war against the Ottoman Empire on the pretext that they would protect the Christian people living in the Balkans. The deteriorating Ottoman State would not have been able to resist Russia alone. Thus, Britain and France began preparing to support the Ottomans against Russia once more. At the beginning of 1854, allied navies began surveying the Gallipoli Peninsula with the thought that they would stop Russia there. However, they were unaware of maps made previously by French and British cartographers, and made no request for Ottoman maps, since they did not appreciate the Ottoman surveyors' work. In fact, those were quite good pieces of workthus, the allied navies' ignorance and arrogance caused them to repeat work unnecessarily (Débarre 2016, pp. 141-142). Ottoman officers, on the other hand, were keen to acquire the maps that their allies had made. For instance, during the Crimean War they immediately adapted a British map into Turkish, and translated an atlas showing the Bosporus and the fortresses along it (Istanbul University Library, 92688 and 92924). They also ordered cartographic instruments from Vienna, with a view to mapping Crimea (BOA, A.\} AMD 60.12.01).

British seamen played an important role during the Crimean War. Thomas Spratt and his team surveyed Balaklava and noted the positions of the allied fleet for the bombardment of Sevastopol (Chasseaud / Boyle 2005, pp. 50-51). Since the Russians assault on Varna instead of the Gallipoli peninsula was contrary to expectations, the surveying work finished earlier. Russia was defeated with the aid of France and Britain, and a treaty was signed in Paris in 1856. Accordingly, the Black Sea became neutral. The political atmosphere was again calm, despite Russia's dissatisfaction.

On the occasion of this peace, the Ottomans fortified the Straits and produced new maps. A manuscript map made by senior captain Nuri Efendi in the military school in 1863 combined all the cartographical resources I have mentioned so far (BOA, HRT 706). (Fig. 2a and 2b) Evidently, this map showing the Bosporus and the Dardanelles, along with Tenedos Island and Troy, is a copy of the map produced after the Ottoman-Russian joint expedition of the Marmara Sea. The depths are given in the Russian measurement unit sazhen as in the original map-an unusual choice since their equivalent values in British feet was more useful. In the legend, some symbols are also written in French. As it turns out, Nuri Efendi did not want to lose time by calculating all of the depth values in another unit, so he instead stated the foot equivalent of one sazhen. This was probably intended to ease the map's reading and comparisons for Ottoman naval officers, who were presumably using British maps, since they had 


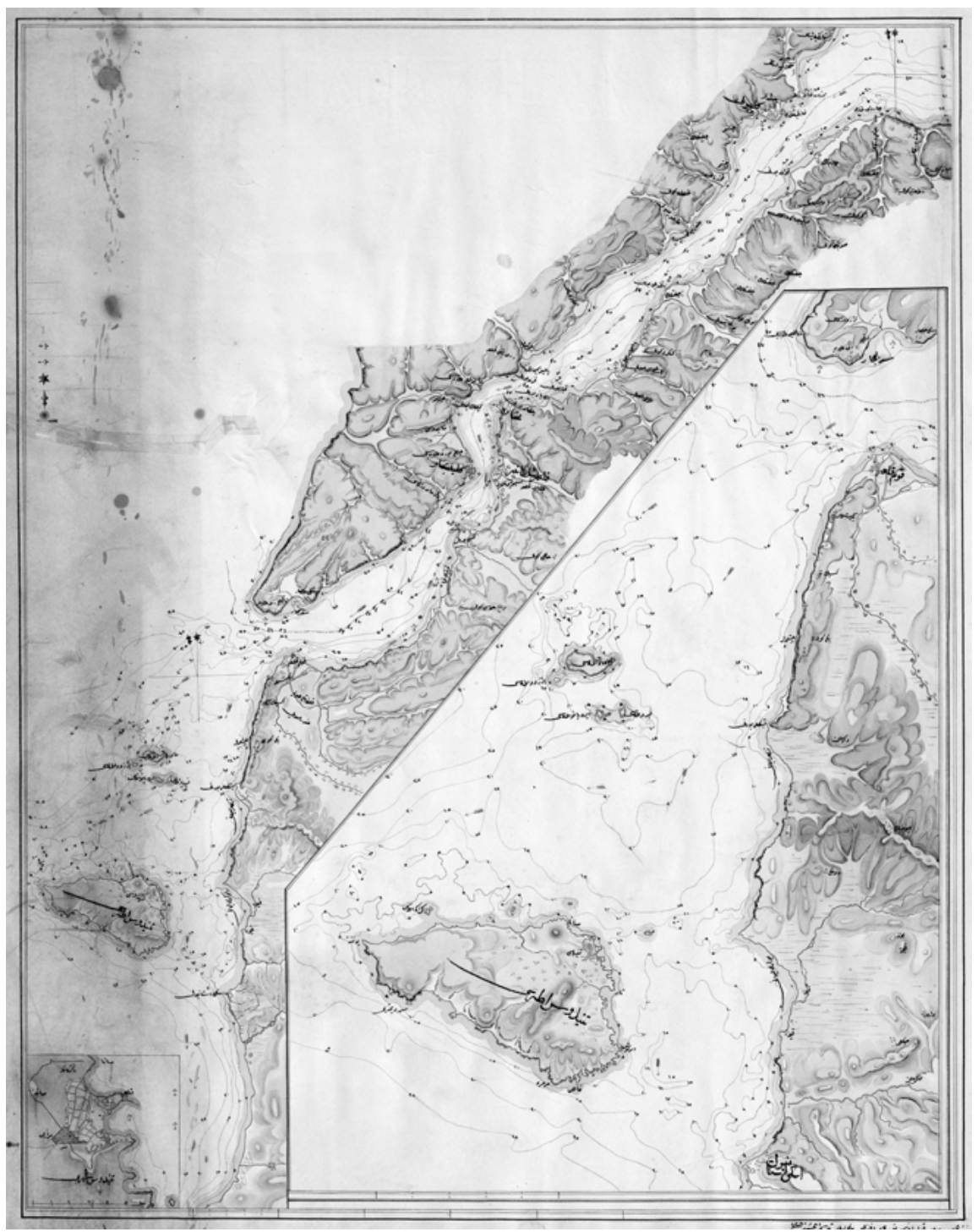

Fig. 2a State Archives of Prime Ministry BOA HRT 706

their education from British officers. As for the French symbols in the legend, this is likely because the first modern cartography teachers of Ottoman officers were French, and as such they had learned the basic rules and technical terms of map-making from them. 


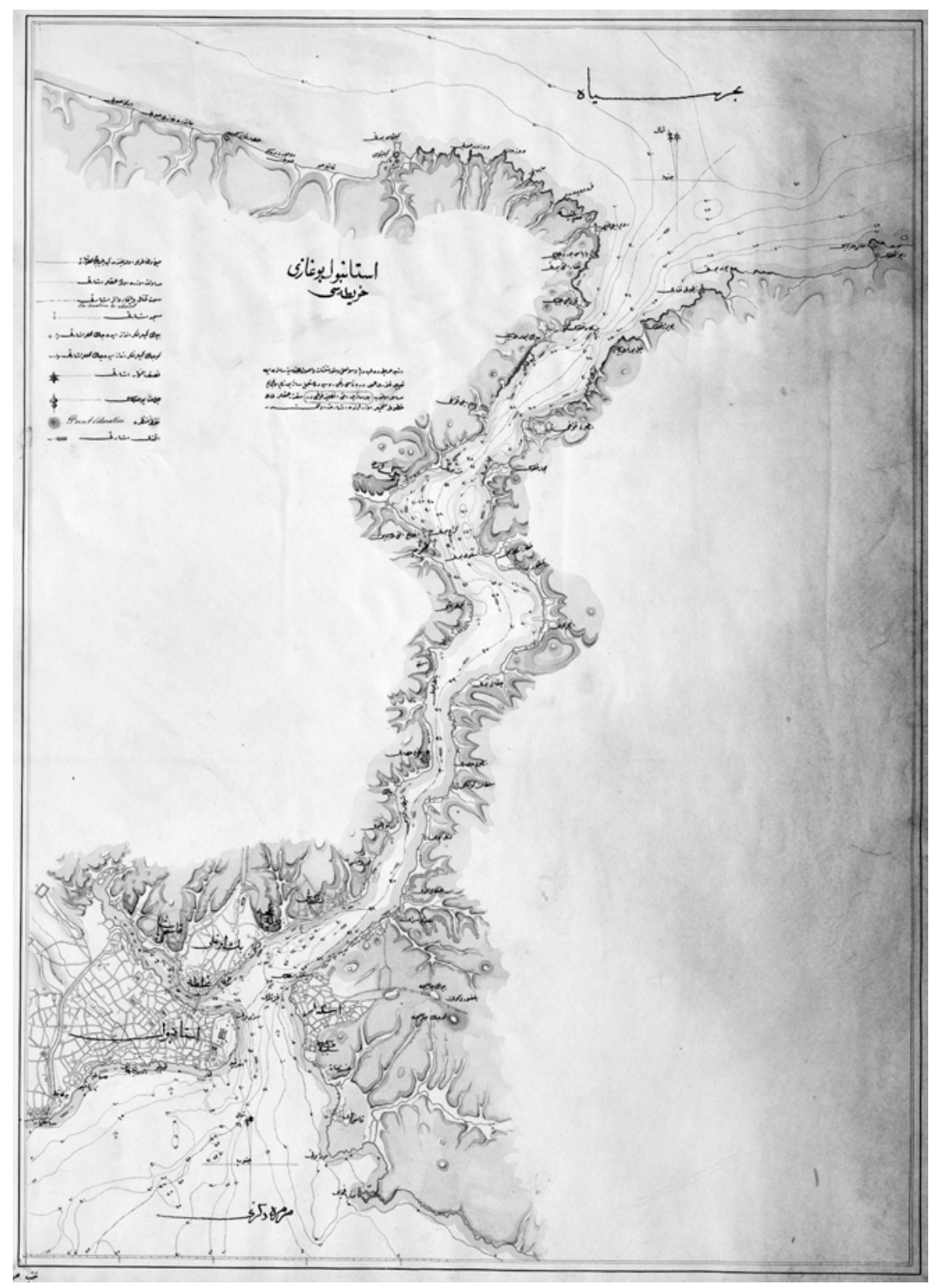

Fig. 2b State Archives of Prime Ministry BOA HRT 709 


\section{Preparations for a new concept}

The Russian Empire took the opportunity to deny the conditions of the Paris treaty by exploiting the instability caused by the German-French war 1870. In response to this, the Ottoman Grand Vizier Âli Pasha (1815-1871) approached Britain and a conference was organized in London in 1871, which abolished the neutrality of Black Sea and gave the Ottomans the right to permit ships of allied navies to sail on it whenever they wished. This was a very important advantage for the Ottoman Empire and a new threat for Russia (Beydilli 1992, p. 267). Subsequently, British commander William J. L. Wharton (1843-1905) led his ship towards the Sea of Marmara, surveyed a small portion of its western part and explored the strong under currents running counter to the surface currents (Dawson 1885, p. 153).

In this context, a second international geographical congress was organized in 1875. All the actors in the 'play' were there to exhibit their geographical productions. However, Russia was the only country exhibiting artifacts concerning the Black Sea and the Sea of Marmara. They exhibited Manganari's aforementioned atlases and maps, alongside some earlier maps (Fournier 1875, p. 16). The absence of newly produced maps at this congress seems to imply that they tried to hide their recent knowledge of those seas in the lead-up to the approaching war between Russia and the Ottoman Empire. This war erupted in 1877 and lasted almost one year. France and Britain only tried to stop this war from afar. The Ottoman Empire was overwhelmed. Russia sought advantages from their absolute victory, but Britain's position ensured the conditions of 1871 London Congress (Beydilli 1992, p. 268).

After this war, the Ottoman State was now well enough aware that its existence was at risk. Hence, it produced and copied new maps of the Sea of Marmara, the Black Sea, and the Straits. An atlas of the Sea of Marmara and the Black Sea consisting of 47 charts was published in the publishing house of the Ottoman Navy in 1878 (Ülkekul 2009, pp. 80-82). Meanwhile, a new British expedition on the Sea of Marmara was run by Captain William Wharton from 1879 to 1880 (Dawson 1885, pp. 188-189). He elaborated the map made in the early nineteenth century by Thomas Graves and Thomas Spratt (Istanbul University Library, 93432). The rocks he circumnavigated in the Sea of Marmara are named after him as the 'Vortonoz Rockies'.

From then on, Britain shifted its attention from the Ottoman territory to the emerging power of Germany, while nevertheless continuing to keep an eye on the 'Eastern Question' (Chasseaud / Boyle 2005, p. 55). The Russian Empire conducted a physical exploration of the Black Sea in 1890 and 1891 and produced charts 
(Andrusoff 1893, p. 49). In 1892 the Ottoman government sent a team to survey and fortify the Straits under the direction of Henri Alexis Brialmont, a Belgian general-but this mission produced no maps (Kış 2015, pp. 365-373).

\section{Concluding/opening remarks}

The year of 1895 was another landmark for Ottoman cartography: an independent cartography office was founded within the army. Additionally, the political atmosphere changed in a way that would eventually lead to the First World War. These two phenomena combined to herald a different era in cartographic production (Özkale ve Şenler 1980, p. 51).

In essence, the 'long' nineteenth century that I have highlighted here witnessed many alliances, treaties and enmities in the context of the 'Eastern Question'. All of the actors taking part in the 'Balance of Power' play that dealt with this question needed profound knowledge of the Marmara Sea, the Black Sea and the Straits. Motivated by a lack of knowledge of this geographical unit, and powered by progress in modern science and technology, a hefty production of cartographical knowledge was accomplished throughout this period. However, these productive map-making activities entailed their share of coalitions and hostilities. The production output of each country fluctuated according to their relations with the other actors. Therefore, even though I have given an overview of this 'long' nineteenth century by touching upon its essential activities and the fruits it bore, this period in history nevertheless serves to corroborate Yves Lacoste's famous statement 'La géographie, ça sert, d'abord, à faire la guerre' ('Geography is used, first and foremost, to make war').

\section{Bibliography}

Aktepe, M. Münir (1993): “Çeşme Vak’ası”. In: Türkiye Diyanet Vakfı İslam Ansiklopedisi 8, pp. $288-289$.

Algül, Emirhan (1985): “Türk Hidrografi Tarihçesi”. In: Harita Dergisi, No. 94, pp. 61-67.

Andrusoff, N. (1893): "Physical Exploration of the Black Sea”. In: The Geographical Journal, Vol. 1 No. 1, pp. $49-51$.

Aygün, Abdurrahman (1936): “Ruslarla Müştereken Karadeniz ve Marmara’nın Mesahası”. In: Haritacılar Mecmuası, No. 13, pp. 61-70.

Beydilli, Kemal (1992): “Boğazlar Meselesi”. In: Türkiye Diyanet Vakfı İslam Ansiklopedisi 6, pp. $266-269$.

Bulatov, Vladimir E. (2000): "Eighteenth-century Russian charts of the straits (Bosporus and Dardanelles)”. In: Imago Mundi, Vol. 52 No. 1, pp. 96-111. 
Bulatov, Vladimir E. / Delano-Smith, Catherine / Herbert, Francis (2001): “Andrew Dury's 'Map of the Present Seat of War, between the Russians, Poles, and Turks' (1769)”. In: Imago Mundi 53, pp. 71-82.

Chausseaud, Peter / Doyle, Peter (2005): Grasping Gallipoli: terrain, maps and failure at the Dardanelles, 1915. Staplehurst: Spellmount.

Dawson, L. S. (1885): Memoirs of Hydrography. Eastbourne: Henry W. Key, The 'Imperial Library'.

Débarre, Ségolène (2016): “Peut-être un nouveau Gibraltar”. In: Pérouse, Jean François / Günergun, Feza (Eds.): Entre Trois Mers: Cartographie ottomane et française des Dardanelles et du Bosphore. Izmir: Arkas Sanat Merkezi, pp. 126-144.

Fournier, Felix (1875): Exposition-Catalogue Général des Produits Exposés. Paris: Typographie Lahure.

Frumin, Mitia (2016): “François Kauffer: un cartographe espion?”. In: Pérouse, Jean François / Günergun, Feza (Eds.): Entre Trois Mers: Cartographie ottomane et française des Dardanelles et du Bosphore. Izmir: Arkas Sanat Merkezi, pp. 94-104.

Goodenough, Edmund (1831): “Memoir on the Voyage of His Majesty's Ship Blonde in the Black Sea”. In: Journal of the Royal Geographical Society of London, Vol. 1, pp. 101-122.

Grinevetsky, Sergei R. et al. (2015): The Black Sea Encyclopedia. Berlin, Heidelberg: Springer. Günergun, Feza / Üçsu, Kaan, (2016): “Petite chronologie des missions de reconnaissance scientifiques, militaires et diplomatiques françaises auprès de la Sublime Porte (milieu de XVIIle-fin du XIXe)". In: Pérouse, Jean François / Günergun, Feza (Eds.): Entre Trois Mers: Cartographie ottomane et française des Dardanelles et du Bosphore. Izmir: Arkas Sanat Merkezi, pp. 66-88.

İnalcık, Halil (1944): "Yeni Vesikalara Göre Kırım Hanlığının Osmanlı Tâbiliğine Girmesi ve Ahidname Meselesi”. In: Belleten 30, pp. 185-229.

İnalcık, Halil (1979): "The Question of the Closing of the Black Sea Under the Ottomans". In: Archeion Pontou 35, pp. 74-110.

İnalcık, Halil (2008a): “Çanakkale Boğazı: Özet ve Kronoloji”. In: Demir, Mustafa (Ed.): Çanakkale Şavaşları Tarihi Vol:1. Istanbul: Değişim Yayınları, pp. 65-70.

İnalcık, Halil (2008b): “Fâtih, Boğazların Tahkimi, Karadeniz; Bir Osmanlı Gölü”. In: Demir, Mustafa (Ed.): Çanakkale Şavaşları Tarihi Vol:1. Istanbul: Değişim Yayınları, pp. 45-52.

Inalcık, Halil (2008c): “Karadeniz'de Kazaklar ve Rusya: İstanbul Boğazı Tehlike’de”. In: Demir, Mustafa (Ed.): Çanakkale Şavaşları Tarihi Vol:1. Istanbul: Değişim Yayınları, pp. 95-64.

Kaçar, Mustafa (2008): “Tersâne Hendesehânesi'nden Bahriye Mektebi’ne Mühendishâne-i Bahrî-i Hümâyûn”. In: Osmanlı Bilimi Araştırmaları, Vol. 9 No. 1-2, pp. 51-77.

Kış, Salih (2015): “Köprü Başlarını Tutmak: Osmanlı Devleti'nin Karadeniz ve Akdeniz Boğazlarını Tahkim Etme Teşebbüsü”. In: Uluslararası Sosyal Araştırmalar Dergisi, Vol. 8 No. 37, pp. 364-375.

Leboutellier, Pascal (2016): “La Cartographie des Détroits dans les institutions militaires ottomanes au XIXe siècle: Un aperçu synoptique à partir des collections de l'Université d'Istanbul”. In: Pérouse, Jean François / Günergun, Feza (Eds.): Entre Trois Mers: Cartographie ottomane et française des Dardanelles et du Bosphore. Izmir: Arkas Sanat Merkezi, pp. 144-174.

Ledonne, John P. (2006): “Geopolitics, Logistics and Grain: Russia's Ambitions in the Black Sea Basin, 1737-1834”. In: The International History Review, Vol. 28 No. 1, pp. 1-41. 
Özcan, Abdülkadir (2001): “Karlof̧̧a Antlaşması”. In: Türkiye Diyanet Vakfı İslam Ansiklopedisi 24, pp. 504-507.

Özkale, Edip / Şenler, Mustafa Rıza (1980): Haritacı Mehmet Şevki Paşa ve Ikinci Meşrutiyet Öncesiyle 1908'den 1918 Yılı Sonuna Kadarki On Yılık Dönemde Osmanlı Ülkesi Haritasının Alımı için Yapılan Örgütlenme ve Işslerin Tarih Özeti. Ankara: Harita Genel Müdürlüğü Basımevi.

Pedley, Mary (2012): “Enlightenment Cartography at the Sublime Porte: François Kauffer and the Survey of Constantinople”. In: Osmanlı Araştırmaları, No. 39, pp. 29-53.

Postnikov, Aleksey V. (2000): "The Russian navy as Chartmaker in the Eighteenth century". In: Imago Mundi, Vol. 52 No.1, pp. 79-95.

Schokalsky, J. de (1907): “A Short Account of the Russian Hydrographical Survey”. In: The Geographical Journal, Vol. 29 No. 6, pp. 626-649.

Üçsu, Kaan (2017): “Ibrahim Müteferrika's map of Black Sea and its copies in Bibliothèque National de France". In: The 27th International Conference on the History of Cartography. Belo Horizonte: Universidade Federal de Minas Gerais.

Ülkekul, Cevat (2009): Türk Seyir, Hidrografi ve Oşinografi çalışmalarının 1909 öncesi tarihi : Deniz Kuvvetleri Komutanlığı Seyir, Hidrografi ve Oşinografi Dairesi Başkanlığı'nın yüzüncü kuruluş yılına armağan. İstanbul: Seyir, Hidrogragi ve Oşinografi Dairesi Başkanlı̆̆ı.

Vagnon, Emmanuelle / Hofmann, Catherine (2016): “A la recherce du passé: Choiseul-Gouffier et la cartographie des Dardanelles au XVIIle siècle”. In: Pérouse, Jean François / Günergun, Feza (Eds.): Entre Trois Mers: Cartographie ottomane et française des Dardanelles et du Bosphore. Izmir: Arkas Sanat Merkezi, pp. 38-60.

Zaytsev, Aleksey K. (2000): “The Three Earliest Charts of Akhtiar (Sevastopol') Harbour”. In: Imago Mundi 52, pp. 112-123.

Zorlu, Tuncay (2011): Innovation and Empire in Turkey: Sultan Selim III and the modernisation of the Ottoman navy. London: Tauris Academic Studies. 